\title{
A thirty years follow-up study on Schistosomiasis mansoni in a community of Minas Gerais, Brazil
}

\author{
Maria José Conceição/ ${ }^{+}$, José Borges-Pereira*, José Rodrigues Coura*
}

\begin{abstract}
Programa de Pós-graduação em Doenças Infecciosas e Parasitárias, Departamento de Medicina Preventiva, Hospital
Universitário Clementino Fraga Filho, Universidade Federal do Rio de Janeiro, Avenida Brigadeiro Trompowsky s/n, Cidade Universitária, Ilha do Fundão, 21941-590 Rio de Janeiro, Brasil *Laboratório de Doenças Parasitárias, Instituto Oswaldo Cruz-

Fiocruz, Rio de Janeiro, Brasil
\end{abstract}

During thirty years - 1973-2003 - a group of individuals infected by Schistosoma mansoni in Capitão Andrade, Rio Doce Valley, Minas Gerais, Brazil, was evaluated by the same authors, being one of the longest follow-up studies on schistosomiasisis mansoni in an endemic area. The diagnosis of $\mathrm{S}$. mansoni was based on parasitological stool tests. In the clinical classification, three groups were considered: type I-schistosomiasis-infection, type II - hepatointestinal form, and type III- hepatosplenic form. The prevalence of infection were $60.8 \%$ in $1973,36.2 \%$ in 1984, 27.3\% in 1994, and 19.4\% in 2003, while the index of hepatosplenomegaly were respectively $5.8 \%, 2.8 \%, 2.3 \%$ and $1.3 \%$. The maintenance of high prevalence and severity of clinical forms are probably related to reinfection.

Key words: schistosomiasis mansoni- follow-up study - thirty years - Minas Gerais - Brazil

Schistosomiasis mansoni continues to be one of the most serious world public health problems, preceded among parasitic diseases only by malaria, and it occurs in 76 countries worldwide. In Brazil, about 12 to 14 million individuals are infected with Schistosoma mansoni. However, a significant reduction in the incidence of severe forms of the disease has been observed over the last 20 years (Andrade 1998, Coura \& Amaral 2004).

Important epidemiological studies have been carried out in different regions of Brazil, in order to understand the parasite-host interface in a more accurate way. In a pioneering study, Jansen (1946) evaluated the prevalence of $S$. mansoni in a population from Catende, Pernambuco (PE), between 1937 and 1941, and started to treat children and adults with antimonial drugs. Reassessment of the same group by Sette (1953), from 1942 to 1951 , revealed that $1.7 \%$ of treated individuals developed the hepatosplenic form, whereas this rate was $9.9 \%$ within the untreated group. Brener and Mourão (1956) and Katz and Brener (1966) re-evaluated 120 inhabitants from the state of Minas Gerais (MG) during 10 years, and showed that under $10 \%$ had a progression to hepatosplenic form. Barbosa (1966), in a seven years longitudinal study on morbidity in Pontezinha, PE, detected significant reduction of prevalence through education for the health and environmental sanitation conditions. Kloetzel (1972), during a follow-up of 11 years in Gameleira, PE, emphasized the use of specific treatment to prevent the severe forms of the disease. In a five years study in Caatinga do Moura, Bahia (BA), a progression of 20 patients over

\footnotetext{
${ }^{+}$Corresponding author: conceicao@ioc.fiocruz.br Received 3 August 2007

Accepted 13 December 2007
}

20 years old from types I and II to type III was verified by Prata and Bina (1968).

A survey on the natural history of infection with $S$. mansoni in Capitão Andrade, MG, conducted in 1973 (Conceição 1976) identified high prevalence and morbidity in the autochthonous population, especially when compared to populations from other endemic areas in Brazil evaluated by the same group of researchers (Coura et al. 1992). The results obtained during this phase showed a prevalence of infection of $60.8 \%$ in Capitão Andrade, with $5.6 \%$ of hepatosplenic forms, and $0.6 \%$ of infantilism. These results have emphasized the high pathogenicity of $S$. mansoni infection in this area. Consequently, a longitudinal study of the infection in this population was started in 1984. Despite the limitations of following-up the case due to the marked migratory flow of inhabitants to and out of the area (Coura et al. 1984), the evaluation was continued in 1993 (Conceição \& Borges-Pereira 2002), and in 2003, accomplishing the 30 years follow-up that is presented in this article.

The municipality of Capitão Andrade, a small town located in Rio Doce Valley, MG, had 5,890 inhabitants in 2003 and a marked migratory flow. For clinical examination, priority was given to the same autochthonous individuals that had been examined in 1973 by the same authors (Conceição 1976), and that remained in the area until 2003. Infection prevalence was determined by three parasitological examinations by the Kato method modified by Katz et al. (1972), and infection burden was based on the number of $S$. mansoni eggs per gram of feces.

Two physicians responsible for the study examined the infected individuals in all phases of the study, without any randomic selection. In order to evaluate liver and spleen sizes, the subjects were examined on dorsal position (during deep expiration) as well as on Schuster position. Patients were included in three groups and so remained for the subsequent phases of the study: type I schistosomiasis-infection, with or without intestinal 
symptoms, which, if present, were moderate and not necessarily attributed to the disease; type II - hepatointestinal form, frequent intestinal symptoms, such as dysenteric diarrhea and hepatomegaly; and type III- hepatosplenic form, very frequent intestinal symptoms dysentery and hepatosplenomegaly, with or without hematemesis or melena. During clinical examination, the individuals were asked about episodes of fever or epistaxis (Conceição \& Borges-Pereira 2002).

Patients with hepatosplenomegaly were admitted to Hospital Universitário Clementino Fraga Filho, and followed up by the teams from the Service of Infectious and Parasitic Diseases and the Department of Surgery. Leucocytes and platelets counting for evaluating hypersplenism, liver function tests, immunoassays aiming to detect hepatitis $\mathrm{B}$ and $\mathrm{C}$ virus, and ultrasonography were requested to determine the portal vein caliber, liver and spleen sizes, and fibrosis. This study was approved by the Ethical Committee of the Instituto de Pesquisas Clínicas Evandro Chagas-Fiocruz (CONEP protocol 0127.0.011.009-05).

Prevalence of S. mansoni decreased from $60.8 \%$ to $36.2 \%$ from 1973 to 1984 , from $36.2 \%$ to $27.3 \%$ from 1984 to 1994 , and from $27.3 \%$ to $19.3 \%$ from 1994 to 2003 (Table). Table shows the evolution of clinical forms. The rate of hepatosplenomegaly were $5.8 \%$ in $1973,2.8 \%$ in $1984,2.3 \%$ in 1994 , and $1.3 \%$ in 2003 . Esophageal varices were confirmed through endoscopy in 20 individuals with hepatosplenomegaly. No case of ascites, cirrhosis or other complications indicating liver involvement was observed.

Between 1973 and 1983, there was a spontaneous decrease in the prevalence registered in the area without any measures of mass treatment (Coura et al. 1984). The reason for this finding may be the improvement of hygiene habits resulted from the development of health education in the region of MG. Amaral et al. (2006) and Guimarães et al. (2006) have described the impact of the schistosomiasis control program in Brazil, especially

\section{TABLE}

Cases of Schistosomiasis mansoni from Capitão Andrade, state of Minas Gerais, Brazil, examined in 1973, 1984 and 1994, and re-examined in 2003

\begin{tabular}{lrrrc}
\hline Evolution & $\begin{array}{r}\text { Positive cases } \\
(\mathrm{n}=86)\end{array}$ & \multicolumn{2}{c}{$\begin{array}{c}\text { Negative cases } \\
(\mathrm{n}=23)\end{array}$} \\
\hline Unchanged & $\mathrm{n}$ & $\%$ & $\mathrm{n}$ & $\%$ \\
\hline Schistosomiasis-infection (Type I) & 62 & 72.1 & 15 & 65.2 \\
Hepatointestinal (Type II) & 8 & 90.5 & 12 & 52.2 \\
Hepatosplenic (Type III) & 2 & 2.3 & 3 & 13.0 \\
In progression & 0 & - & 2 & - \\
Type I $\Rightarrow$ II & 0 & - & 2 & 8.7 \\
Type II $\Rightarrow$ III & 0 & - & 0 & - \\
In regression & 24 & 27.9 & 6 & 26.1 \\
Type II $\Rightarrow$ I & 24 & 27.9 & 4 & 17.4 \\
Type III $\Rightarrow$ II & 0 & - & 2 & 8.6 \\
\hline
\end{tabular}

in MG. Treatment with oxamniquine was initiated in 1984 in Capitão Andrade. One year latter, no progression from the mild to a more severe clinical form was observed. In 1994, the same individuals from the population followed up since 1973 were reevaluated. The index of hepatosplenic patients was reduced (2.3\%), and no case of hypogonadism or hypersplenism was detected (Conceição \& Borges-Pereira 2002).

JC Bina (unpublished observations), monitoring the evolution of infection with $S$. mansoni in Taquarendi, $\mathrm{BA}$, proposed some variables that might interfere in the development of hepatomegaly and/or splenomegaly, such as racial factor, intensity of infection and reinfection. In the present study area, despite a marked reduction in the prevalence of infection without treatment procedures during the initial phase (1973-1984), followed by a specific treatment with oxamniquine in 1984-1994, the index of severe forms and the prevalence of S. mansoni have continued high from 1994 to 2003. People continued to receive treatment in this period. There was no improvement in basic sanitation conditions nor in potable water supply; only sanitary education for exposed population was enhanced. We concluded that re-infections have probably influenced such levels of morbidity.

\section{ACKNOWLEDGMENTS}

To Acyr Corrêa, Maria de Lourdes Gomes de Carvalho and Antônio Carlos Júnior for the technical assistance. In memoriam, to Drs. Carlos Alberto Argento, Henry Percy Willcox, Heleno Tinoco de Carvalho, and Mozart José Coelho our colleagues and friends.

\section{REFERENCES}

Amaral RS, Tauil PL, Lima DD, Engels D 2006. An analysis of the impact of the schistosomiasis control programme in Brazil. Mem Inst Oswaldo Cruz 101 (Suppl. I): 79-85.

Andrade Z 1998. The situation of hepatosplenic Schistosomiasis in Brazil. Mem Inst Oswaldo Cruz 93 (Suppl. I): 58-75.

Barbosa FAS 1965. Morbidade da Esquistossomose. Estudo em quatro localidades no Estado de Pernambuco. Rev Bras Malar D Trop 3: 3-159.

Brener Z, Mourão OC 1956. Inquéritos clínico-epidemiológicos em focos endêmicos de esquistossomose mansoni. Rev Bras Malar D Trop 8: 519-526.

Conceição MJ 1976. Morbidade da esquistossomose mansoni em uma comunidade rural de Minas Gerais. MSc Thesis, Universidade Federal do Rio de Janeiro, Rio de Janeiro, 91pp.

Conceicão MJ, Borges-Pereira J 2002. Influence of specific treatment on the morbidity of schistosomiasis mansoni in an endemic area of Minas Gerais, Brazil. Mem Inst Oswaldo Cruz 97: 753-757.

Coura JR, Amaral RS 2004. Epidemiological and control aspects of schistosomiasis in Brazilian endemic areas. Mem Inst Oswaldo Cruz 99 (Suppl. I): 13-19.

Coura JR, Conceição MJ, Borges-Pereira J 1984. Morbidade da esquistossomose mansoni no Brasil. III. Estudo evolutivo em uma área endêmica no período de dez anos. Mem Inst Oswaldo Cruz 79: 447-453.

Coura JR, Conceição MJ, Santos ML, Mendonça MZG, Cutrim RNM 1992. Cross-sectional and evolutive studies of schisto- 
somiasis mansoni in untreated and mass treated endemic areas in the Southeast and Northeast of Brazil. Mem Inst Oswaldo Cruz 87 (Suppl. IV): 175-182.

Guimarães RJPS, Freitas CC, Dutra LV, Moura ACM, Amaral RS, Drummond SC, Guerra M, Scholte RGC, Freitas CR, Carvalho OS 2006. Analysis and estimative of schistosomiasis prevalence for the state of Minas Gerais, Brazil, using multiple regression with social and environmental spatial data. Mem Inst Oswaldo Cruz 101 (Suppl. I): 91-96.

Jansen G 1946. Profilaxia experimental da esquistossomose de Manson. Mem Inst Oswaldo Cruz 44: 549-578.

Katz N, Brener Z 1966. Evolução clínica de 112 casos de Esquistossomose mansoni observados após 10 anos de permanência em focos endêmicos de Minas Gerais. Rev Inst Med Trop $S$ Paulo 8: 139-142.

Katz N, Chaves A, Pellegrino J 1972. A simple device for a quantitative stool thick-smear technique in schistosomiasis. Rev Inst Med Trop S Paulo 14: 397-400.

Kloetzel K. 1972. Perspectivas para o Controle de Esquistossomosedoença. Rev Soc Bras Med Trop 6: 413-420.

Prata AR, Bina JC 1968. Development of the hepatosplenic form of schistosomiasis. Gaz Méd Bahia 68: 49-60.

Sette H 1953. O tratamento da esquistossomose à luz da patologia hepática (Estudo clínico), Thesis, Universidade Federal de Pernambuco, Recife, 220 pp. 
